DOI: http://dx.doi.org/10.1590/fst.2014.0036

\title{
The influence of peeling and type of drying on chemical and sensorial analysis of organic coffee
}

\author{
Maria de Fátima Caixeta FERNANDES ${ }^{1}$, Adriano Bortolotti da SILVA ${ }^{1}$, \\ Nelma de Mello Silva OLIVEIRA ${ }^{1 *}$, José Messias MIRANDA ${ }^{1}$
}

\begin{abstract}
Organic coffee is characterized by being produced without the use of chemical products and by having a similar or superior quality in comparison to that of coffee produced by traditional methods. The production of organic coffee does not include the use of highly soluble nutrients, which makes consumers concerned with environmental issues and healthy eating habits realize its true value. This paper aims to analyze the influence of harvesting, peeling and drying on the quality of organic coffee, in order to present the best way of producing high quality coffee. Samples of organic coffee were harvested by both conventional and selective ways, and some were peeled. They were then dried on concrete patio and on suspended terraces. The beans were analyzed for potassium leaching, electrical conductivity, titratable acidity, and submitted to coffee cupping-test. The results obtained indicated that the selective harvesting of the peeled or unpeeled cherry coffee dried on concrete terrace is feasible for production of fine coffees. This type of processing effectively influenced the final quality of the organic coffee, thus being an alternative to improve the quality and market value of the product, especially for small producers, cooperatives, and associations of coffee producers.
\end{abstract}

Keywords: parchment coffee; postharvest; beverage; quality.

\section{Introduction}

Coffee production aimed at differentiated markets requires special effort of coffee grower over during various stages of the production system. Among alternatives for producing special drinks, a new method has become popular, mainly in Southern Minas Gerais state, through the use of parchment coffee (PC) technology, which aims to provide a good quality coffee production system (Oliveira et al., 2005; Cunha et al., 2003). This technique is based on the mechanical peeling of the ripe fruit in order to remove most of the layer of soft pulp that surrounds coffee beans, keeping, however, the mucilagenous layer that surrounds the beans partially untouched. The beans will then be submitted to mechanical drying (Cunha et al., 2003).

A decisive factor for the adoption of this technique is the high price set by farmers due to the product quality improvement.

Oliveira et al. (2005) reported that parchment coffee produce low-acidity, sweet taste, and intense aroma beverage, which makes it a great potential market.

Organic coffee is characterized by the use of organic fertilizer, good practices for soil management, water conservation, and recycling of plant and animal organic waste. This system adopts ecological and integrated management of pests and diseases. The main difference between organic and conventional coffee is that organic producers restrict the use of chemical fertilizers and prohibit the use of pesticides (Theodoro et al., 2003).
Organic products have a superior quality when compared to those produced in the conventional way, mainly in the case of coffee, whose aroma and taste are heavily influenced by the chemical composition of the beans, which, in turn, is directly related to the organic fertilizer and pre and after-harvest treatment (Silva et al., 2005). Brennan \& Kuri (2002) showed that organic product acceptance is influenced by sensory attributes. Silva et al. (2005) stated that some organic coffee brands have greater consumer market acceptance in addition to having several attributes that can increase or decrease this product consumption (Dantas et al., 2004). Label and its contents (brand, price, printed information) can generate expectation and change consumer perception (Deliza et al., 2003). Lucia et al. (2009) highlighted that the packaging of organic coffee must carry the organic label and information about the benefits of consuming organic products for both people and environment.

Several studies have been conducted to characterize coffee beans chemically and show the relationship of chemical composition and the quality of the beverage. Coffee beans have several volatile and non-volatile compounds such as acids, aldehydes, ketones, sugars, proteins, amino acids, fatty acids, carbohydrates, trigonelline, phenolic compounds, caffeine, and enzymes (Franca et al., 2004).

The aim of the present study was to evaluate the influence of the harvesting method, peeling, and drying on the quality of organic coffee produced in the Southern Minas Gerais state.

Received 24 May, 2013

Accepted 19 Feb., 2014 (006112)

${ }^{1}$ Biology and Physiology of Microorganisms Laboratory, José do Rosário Vellano University - UNIFENAS, Rod. MG179, km 0, CP 23, CEP 37130-000, Alfenas, MG, Brasil, e-mail:nelma.oliveira@unifenas.br

${ }^{*}$ Corresponding author 


\section{Materials and methods}

Eight-year-old samples of 'Mundo Novo' (Coffea arabica L.) were used in this study, were produced on organic farms. The study was conducted in the municipality of Poço Fundo, one of the most important family farming community, which is located between $21^{\circ} 46^{\prime} 51^{\prime \prime} \mathrm{S}$ and $45^{\circ} 57^{\prime} 54^{\prime \prime} \mathrm{W}$, South of the State of Minas Gerais, Brazil. The climate is classified as tropical of altitude $(\mathrm{CWb})$, with an average annual temperature of $23^{\circ} \mathrm{C}$, annual precipitation of $1456 \mathrm{~mm}$, and $836 \mathrm{~m}$ of altitude (Instituto Nacional de Meteorologia, 2009).

A randomized block design (RB) consisting of a $2 \times 2$ factorial experiment with two drying process (cement terrace or suspense terrace) and two types of processing (peeled and unpeeled beans) for selective harvesting. In addition, two additional conventional harvesting control treatments including drying on concrete patio or suspended terrace were performed, totaling six treatments with three repetitions.

The treatments were composed of organic coffee harvested selectively (composed of cherry coffee only) and there was no separation of the beans in the conventional harvesting. The cherry beans were either submitted to peeling (Parchment coffee) or not (Cherry coffee), according to the treatment.

After harvest, three 1-liter samples were withdrawn and stored to compose each treatment. These samples were dried according to different treatments. Harvest was performed in the morning on August 11th, 2009.

Selective harvesting included only by cherry beans, which were picked manually and stored in plastic boxes. Cherry beans were peeled or not, according to the treatments. In the conventional harvest system, fruits (a mixture of coffee beans in different stages of maturation) were picked manually and stored on a piece of cloth.

Suspended terrace consists of a polypropylene mesh $(4 \mathrm{~mm})$ stretched over a flat-wire structure measuring $(3 \times 50 \mathrm{~m})$ suspended $50 \mathrm{~cm}$ above the ground level so that the beans are off the ground.

On the suspended terrace, the beans were spread out, and when they reached a stage of semi-dryness $(50 \%)$ or were half dry, they were piled up daily. In this type of terrace, the parchment coffee (PC) was exposed to the sun for 15 days, and the cherry coffee (CC) for 25 days. As for the traditional drying on the concrete patio coffee beans were spread in thin layers, and when they were half dry, they were piled up daily. CC was exposed to the sun for 30 days, and PC for 10 days. During the night and rainy periods, the patio was covered to avoid excessive humidity. The beans with moisture around 11-12\% (wb) were assessed by different methods.

The coffee beans were evaluated for electrical conductivity, potassium leaching, and titratable acidity and were classified according to the beverage type. The experiments were carried out at EPAMIG - Laboratory of Quality of Coffee "Dr. Alcides Carvalho", Lavras, MG, Brazil.

Electrical conductivity was determined according to the method proposed by Loeffler et al. (1988), and potassium leaching was determined according to the method proposed by Prete (1992).

Titratable acidity was determined using the AOAC official method (Association of Official Analytical Chemists, 1990), adapted to coffee by Carvalho et al. (1994) by taking $5 \mathrm{~mL}$ of the filtrate and adding $50 \mathrm{~mL}$ of distilled water, three drops of phenolphthalein; it was titrated with $\mathrm{NAOH} 0.1 \mathrm{~N}$ solution. It was expressed in $\mathrm{mL}$ of $\mathrm{NaOH} 0,1 \mathrm{~N}$ for each $100 \mathrm{~g}$ of sample

The classification according to the beverage type was performed by three tasters accredited with the Brazil Specialty Coffee Association (BSCA) at the Family Farmers Association of Poço Fundo - COOPFAM. Specialty Coffee Association of America (SCAA) method was used to classify the coffee beverage.

According to this method, each attribute evaluated (fragrance, uniformity, absence of defects, sweetness, flavor, acidity, body, remaining flavor, balance or equilibrium and overallscore. Each attribute evaluated was given a score from $0-10$, according to the samples 'characteristics'. Final score is the sum of the attributes evaluated, and coffees that score higher than 80 points are considered specialty coffees.

The results of the sensory analysis of the control treatments were compared with the 4 treatments using the test $\mathrm{t}$ with Bonferroni protection (Johnson \& Wichern, 1998). Titrable acidity, electrical conductivity, and potassium leaching data were submitted to analysis of variances (ANOVA), using the SISVAR4.3 software program (Ferreira, 2011), and the means were compared using the Scott \& Knott Test.

\section{Results and discussion}

There was a significant interaction $(\mathrm{p}<0.05)$ between the factors for electrical conductivity, potassium leaching, and titratable acidity (Table 1).Parchment coffee (PC) drying on concrete patio had the lowest values of electrical conductivity

Table 1. Electrical conductivity (A), potassium leaching (B), and titratable acidity $(\mathrm{C})$, as a function of peeled or unpeeled cherry beans and drying coffee process for selective and conventional harvesting.

\begin{tabular}{|c|c|c|}
\hline \multicolumn{3}{|c|}{ Electrical Conductivity $\left(\mu \mathrm{S} . \mathrm{cm}^{-1} \cdot \mathrm{g}^{-1}\right.$ sample $)$} \\
\hline Selective harvesting & Concrete patio & Suspense terrace \\
\hline Parchment Coffee (PC) & $151.75 \pm 1.59 \mathrm{Bb}$ & $193.17 \pm 4.91 \mathrm{Aa}$ \\
\hline Cherry Coffee (CC) & $228.73 \pm 1.56 \mathrm{Aa}$ & $211.23 \pm 0.86 \mathrm{Aa}$ \\
\hline Conventional harvesting* & $245.35 \pm 1.61 \mathrm{Aa}$ & $212.29 \pm 3.58 \mathrm{Ab}$ \\
\hline \multicolumn{3}{|c|}{ Potassium Leaching (ppm. $\mathrm{g}^{-1}$ sample) } \\
\hline Selective harvesting & Concrete patio & Suspense terrace \\
\hline Parchment Coffee (PC) & $37.13 \pm 0.49 \mathrm{Bb}$ & $51.26 \pm 0.85 \mathrm{Aa}$ \\
\hline Cherry Coffee (CC) & $58.23 \pm 0.80 \mathrm{Aa}$ & $59.39 \pm 0.57 \mathrm{Aa}$ \\
\hline Conventional harvesting* & $64.16 \pm 2.20 \mathrm{Aa}$ & $54.15 \pm 1.10 \mathrm{Ab}$ \\
\hline \multicolumn{3}{|c|}{ Titratable Acidity (mL of $\mathrm{NaOH} 0,1 \mathrm{~N} .100 \mathrm{~g}^{-1}$ sample) } \\
\hline Selective harvesting & Concrete patio & Suspense terrace \\
\hline Parchment Coffee (PC) & $200.00 \pm 0.10 \mathrm{Cb}$ & $225.00 \pm 0.05 \mathrm{Ba}$ \\
\hline Cherry Coffee (CC) & $225.00 \pm 0.10 \mathrm{Bb}$ & $256.66 \pm 5.80 \mathrm{Aa}$ \\
\hline Conventional harvesting* & $300.00 \pm 0.05 \mathrm{Aa}$ & $250.00 \pm 0.10 \mathrm{Ab}$ \\
\hline
\end{tabular}

Averages followed by the same capital letter vertically or lower case horizontally do not differ by Scoot-Knott test, $5 \%$ probability. ${ }^{*}$ Additional treatments. 
Table 2. Coffee cupping scores of fragrance (FC); uniformity (UF); absence of defects (AD); sweetness (SW); flavor (FV); acidity (AC); body (BD); remaining flavor (RF); balance (BC), overall score (OS), and different parameters.

\begin{tabular}{cccccccccccc}
\hline \multirow{2}{*}{ TREAT } & \multicolumn{10}{c}{ CUPPING } \\
\cline { 2 - 11 } & FC & UF & AD & SW & FV & AC & BD & RF & BC & OS & Total \\
\hline PCCT & $8.0 \mathrm{a}$ & $8.3 \mathrm{~b}$ & $9.0 \mathrm{a}$ & $8.3 \mathrm{a}$ & $9.0 \mathrm{a}$ & $6.6 \mathrm{a}$ & $8.0 \mathrm{a}$ & $9.0 \mathrm{a}$ & $8.0 \mathrm{a}$ & $8.0 \mathrm{~b}$ & $82.6 \pm 0.7 \mathrm{a}$ \\
PCST & $7.0 \mathrm{~b}$ & $7.6 \mathrm{~b}$ & $8.3 \mathrm{~b}$ & $7.6 \mathrm{a}$ & $8.0 \mathrm{~b}$ & $7.3 \mathrm{a}$ & $7.6 \mathrm{a}$ & $8.3 \mathrm{~b}$ & $7.6 \mathrm{a}$ & $8.3 \mathrm{~b}$ & $77.1 \pm 0.3 \mathrm{~b}$ \\
CCCT & $8.3 \mathrm{a}$ & $9.3 \mathrm{a}$ & $8.6 \mathrm{~b}$ & $7.0 \mathrm{a}$ & $8.0 \mathrm{~b}$ & $7.0 \mathrm{a}$ & $8.0 \mathrm{a}$ & $8.6 \mathrm{~b}$ & $8.0 \mathrm{a}$ & $9.0 \mathrm{a}$ & $82.1 \pm 0.5 \mathrm{a}$ \\
CCST & $7.0 \mathrm{~b}$ & $8.6 \mathrm{~b}$ & $8.0 \mathrm{~b}$ & $7.6 \mathrm{a}$ & $7.3 \mathrm{~b}$ & $7.0 \mathrm{a}$ & $7.6 \mathrm{a}$ & $7.0 \mathrm{~b}$ & $7.3 \mathrm{a}$ & $7.6 \mathrm{~b}$ & $75.2 \pm 0.6 \mathrm{~b}$ \\
CHST $^{*}$ & $6.6 \mathrm{~b}$ & $8.0 \mathrm{~b}$ & $8.0 \mathrm{~b}$ & $7.6 \mathrm{a}$ & $8.0 \mathrm{~b}$ & $6.6 \mathrm{a}$ & $7.3 \mathrm{a}$ & $8.0 \mathrm{~b}$ & $7.3 \mathrm{a}$ & $8.0 \mathrm{~b}$ & $76.1 \pm 0.5 \mathrm{~b}$ \\
CHCT $^{*}$ & $7.0 \mathrm{~b}$ & $8.0 \mathrm{~b}$ & $8.0 \mathrm{~b}$ & $8.0 \mathrm{a}$ & $8.0 \mathrm{~b}$ & $7.6 \mathrm{a}$ & $7.3 \mathrm{a}$ & $7.8 \mathrm{~b}$ & $8.3 \mathrm{a}$ & $8.0 \mathrm{~b}$ & $78.1 \pm 0.6 \mathrm{~b}$ \\
\hline
\end{tabular}

Means followed by the same lower case letter in a column do not differ from the control treatments by the t-test and Bonferroni correction. Treatments (TREAT); Parchment coffee (PC); Cherry coffee (CC); Concrete patio (C); Suspense (S) and Terrace (T); Conventional Harvesting (CH). ${ }^{*}$ Control. SCAA Classification: Special rare (90-100); Special original (85-89.99); Special premium (80-84.99); Non-special $(<80)$.

and potassium leaching (Table 1A, B) and higher beverage quality (Table 2). In low quality coffee beans, whose cell membranes have been damaged, there is an overflow of the solute with high electrolyte concentrations with high electrical conductivity or high concentration of ions, specially potassium (Nascimento et al., 2008); therefore it is considered an indicator of membrane integrity (Borém et al., 2006). The treatments with lower potassium leaching tended to have lower electrical conductivity (Table 1A, B).

According to Prete (1992), the degeneration of cell membranes and the loss of permeability control are major factors that characterize coffee bean deterioration resulting in a poor quality beverage. The same author found a positive correlation between the electrical conductivity values ( 84 to $129 \mu \mathrm{S} \mathrm{cm}^{-1}$. $\mathrm{g}^{-1}$ ) and a better quality beverage. However, Favarin et al. (2004) found that electrical conductivity between 123-168 $\mu \mathrm{S} . \mathrm{cm}^{-1}$. $\mathrm{G}^{-1}$ yielded excellent coffee drink; their results are similar to those found in the present paper.

With regard to drying in suspended terraces, coffee beans from conventional harvesting had lower electrical conductivity and potassium leaching values, when compared to those dried on concrete patio (Table 1A, B), thereby indicating that the type of drying can influence the quality of coffee. This fact can be attributed to the better aeration during drying, thus preventing the undesirable fermentation during the process.

The peeling of organic $\mathrm{PC}$ and those dried on concrete patio are of great importance to prevent great losses of potassium ions, thus providing greater cell membrane integrity demonstrating superior quality when compared to that of the other treatments (Table 1A, B). Borém et al. (2008) working with PC dried on concrete patio, observed lower electrical conductivity and potassium leaching when compared to those of the coffee harvested by conventional harvesting dried on concrete patio.

Titratable acidity value is related to the total concentration of acids in the sample (Franca et al., 2004), and it is inversely proportional to coffee quality since high acidity ratings are indicative of low quality coffee beverage (Carvalho et al., 1994). According to the parameters presented before, the treatment in which the coffee beans were harvested selectively, in the form of PC and dried on concrete patio, had lower titratable acidity values (Table 1C). Borém et al. (2008) observed a decrease in acidity as a consequence of the cherry coffee (PC) pulping.
Afonso Junior (2001) found an increase in titratable acidity in natural coffee since due to the mucilage fermentation there is an increase in the acidification of the beans.

Resende et al. (2011) reported that increased titratable acidity is related to breakdown caused by increased temperature during the coffee drying process, resulting in higher electrical conductivity and possibly greater membrane degradation. Greater titratable acidity and electrical conductivity was observed in coffee from conventional harvesting dried on concrete patio (Table 1A, C). In the present study, drying on a suspended terrace may have reduced the temperature of the coffee beans, which led to titratable acidity lower than that of the conventional harvesting on concrete patio (Table 1C).

Carvalho et al. (1994) demonstrated the occurrence of excellent beverage with acidity of $250.4 \mathrm{~mL} \mathrm{NaOH} 0.1 \mathrm{~N} .100 \mathrm{~g}^{-1}$. Most of the treatments tested showed values lower than those described by Carvalho et al. (1994), which can show the good quality of the PC (Silva et al., 2004), dried on concrete patio and suspended terrace, and CC dried on concrete patio (Table 1C).

The quality of a given coffee batch can be expressed through a centesimal numerical scale. High scores are attributed to coffees the best cupping quality (Specialty Coffee Association of America, 2008). According to the SCAA protocol, coffee with grades higher than $80 \%$ are considered special and may be exported to specific markets, such as the North America, since it meets quality and sustainability requirements.

Selective harvesting treatments, PC, or CC with drying on concrete patio (PCCT/CCCT) were classified as specialpremium coffees according to beverage quality (cupping quality) following the SCAA parameters (Table 2). Nascimento et al. (2008), investigating washed coffee cherry obtained cupping grade levels close to $81 \%$, value assigned regarding aspects such as taste, aftertaste, sweetness, body, and acidity among others.

Sensory attributes of coffee showed significant differences when compared to the conventional harvesting drying on concrete patio or suspense terrace (CHST/CHCT) and selective harvesting (PCCT/CCCT). The highest score for fragrance (FC), which represents the smell of roasted coffee powder, was observed in PCCT and CCCT treatments (Table 2). CCCT treatment showed the highest uniformity (UF), i.e., better uniformity among the samples tested by the tasters. The highest 
score for absence of defects (AD) was verified in the treatment PCCT. In this attribute, the tasters evaluate the absence of defects in the coffee beverage, i.e., high scores are related to the presence of minor sample defects.

Flavor is an important characteristic of coffee, representing the intensity, quality, and complexity of the combination of taste and aroma. The PCCT treatment had the best score for this attribute. The PCCT treatment had the best remaining flavor $(\mathrm{RF})$, which is defined as the persistence of coffee characteristics perceived by the palate. The highest overall score (OS) was observed in the CCCT treatment. This attribute shows the consistency and stability of the scores given by the tasters for the different attributes (Table 2).

The parameters sweetness, acidity, and body, evaluated in the sensory analysis were not significant (Table 2). Sweetness (SW) represents the presence of certain carbohydrates in the samples. In the present study, its score were higher than seven (Table 2). The acidity score ranged between 6-7. This attribute is associated with perceived sweetness; however, if it is too high it can result in a poor quality coffee classification.

The attribute body was given scores between 7-8 in the different treatments. This attribute reflects the tactile perception of the liquid in the mouth, in terms of quality; an intense body is due to the increased presence of soluble solids in the beverage.

The lowest values of electrical conductivity and potassium leaching observed in PC dried onconcrete patio (Table 1A, B), led to classification as special beverage (Table 2). Borém et al. (2006) observed that lower values of electrical conductivity and potassium leaching are related to a better quality beverage. The same behavior was not observed in the CC treatment with drying on concrete patio, which although having higher values of electrical conductivity and potassium leaching (Table 1A, B) had special coffee beverage classification (Table 2).

Malta et al. (2005) related increased electrical conductivity and potassium leaching with the presence of green, brocades, and burned coffee beans. Coelho \& Pereira (2002) stated that the presence of defects, mainly, green beans affects the quality of the beverage. This fact may explain the better quality of the drinks of the PCCT and CCCT treatments (selective harvesting) when compared with the control treatments (conventional harvesting), which are a mixture of coffee beans in different stages of maturation (Table 2). However, it does not explain the behavior of PCST and CCST treatments (selective harvesting), which are similar to that of conventional harvesting (Table 2). The coffee beverage quality depends on the species and location of coffee crop, the stage of maturation of the fruits, and postharvest operations (Resende et al., 2011).

The use of electrical conductivity, potassium leaching, and titratable acidity still has limitations that could hinder coffee grading; therefore it is necessary to make changes and control the different factors that affect these tests (climatic conditions, cultivate, harvest season, and drying process among others), to reduce errors leading to a positive correlation between the chemical tests and the sensory analysis (Favarin et al., 2004; Malta et al., 2005). Meanwhile, sensory analysis will be used as a standard method to assess coffee beverage quality classification.

\section{Conclusion}

The quality of the beverage made from cherry coffee is influenced by the postharvest handling of the fruit. The drying of the cherry coffee (PC or CC) on concrete patio produces top quality coffee beverage when compared with the drying process in suspended terrace. Rapid chemical analyses cannot yet substitute sensory evaluation and should be improved to be used in quality tests of coffee subjected to different postharvest treatments.

\section{Acknowledgements}

The authors are grateful for the financial support provided by Minas Gerais State Research Foundation (FAPEMIG).

\section{References}

Afonso Junior, P. C. (2001). Aspectos físicos, fisiológicos e da qualidade do café em função da secagem e do armazenamento (Tese de doutorado). Universidade Federal de Viçosa, Viçosa.

Association of Official Analytical Chemists - AOAC. (1990). Official methods of analysis. 15th ed. Washington: AOAC.

Borém, F. M., Coradi, P. C., Saath, R., \& Oliveira, J. A. (2008). Qualidade do café natural e despolpado após a secagem em terreiro e com altas temperaturas. Ciência e Agrotecnologia, 32(5), 1609-615. http:// dx.doi.org/10.1590/S1413-70542008000500038

Borém, F. M., Riberio, D. M., Pereira, R. G. F. A., Rosa, S. D. V. F., \& Moraes, A. R. (2006). Qualidade do café submetido a diferentes temperaturas, fluxos de ar e períodos de pré-secagem. Coffee Science, 1(1), 55-63.

Brennan, C. S., \& Kuri, V. (2002). Relationship between sensory attributes, hidden attributes and price in influencing consumer perception of organic foods. In Proceedings of the UK Organic Research 2002 Conference, Organic Centre Wales.

Carvalho, V. D., Chagas, S. J. R., Chalfoun, S. M., Bortrel, N., \& Juste Júnior, E. S. G. (1994). Relação entre a composição físico-química e química do grão beneficiado e a qualidade de bebida do café. Pesquisa Agropecuária Brasileira, 29(3), 449-54.

Coelho, K. F., \& Pereira, R. G. F. A. (2002). Influência de grãos defeituosos em algumas características químicas do café cru e torrado. Ciência e Agrotecnologia, 26(2), 375-384.

Cunha, M. L., Canto, M. W., \& Marsaioli, J. R. A. (2003). Secagem de café cereja descascado por ar quente e microondas. Ciência e Tecnologia de Alimentos, 23(3), 381-5. http://dx.doi.org/10.1590/ S0101-20612003000300015

Dantas, M. I. S., Minim, V. P. R., Deliza, R., \& Puschmann, R. (2004). The effect of packaging on the perception of minimally processed products. Journal of International Food \& Agribusiness Marketing, 16(2), 71-83. http://dx.doi.org/10.1300/J047v16n02_05

Deliza, R., Rosenthal, A., \& Silva, A. L. S. (2003). Consumer attitude towards information on non-conventional technology. Trends in Food Science \& Technology, 14(1-2), 43-49. http://dx.doi. org/10.1016/S0924-2244(02)00240-6

Favarin, J. L., Villela, A. L. G., Moraes, M. H. D., Chamma, H. M. C. P., Costa, J. D., \& Dourado Neto, D. (2004). Qualidade da bebida de café de frutos cereja submetidos a diferentes manejos pós-colheita. Pesquisa Agropecuária Brasileira, 39(2), 187-192. http://dx.doi. org/10.1590/S0100-204X2004000200013

Ferreira, D. F. (2011). Sisvar: A computerstatisticalanalysis system. Ciência e Agrotecnologia, 35(6), 1039-42. 
Franca, A. S, Mendonça, J. C. F., \& Oliveira, S. S. D. (2004). Composition of green and roasted coffees of different cup qualities. LWT-Food Science and Technology, 38, 709-15. http://dx.doi.org/10.1016/j. lwt.2004.08.014

Instituto Nacional de Meteorologia - INMET. (2009). Banco de Dados Meteorólogicos para Ensino e Pesquisa - BDMEP. Retrieved from http://www.inmet.gov.br/portal/.

Johnson, R. A., \& Wichern, D. W. (1998). Applied multivariate statistical analysis. 4th ed. New Jersey: Prentice Hall.

Loeffler, T. M., Tekrony, D. M., \& Egli, D. B. (1988). The bulk conductivity test as an indicator of soybean quality. Journal of Seed Technology, 12(1), 37-53.

Lucia, S. M. D., Minim, V. P. R., Minim, L. A., \& Osório Silva, C. H. (2009). Características visuais da embalagem de café no processo de decisão de compra pelo consumidor. Ciência e Agrotecnologia, 33(spe), 1758-1764. http://dx.doi.org/10.1590/ S1413-70542009000700010

Malta, M. R., Pereira, R. G. F. A., \& Chagas, S. J. R. (2005). Condutividade elétrica e lixiviação de potássio exsudato de grãos de café: alguns fatores que podem influenciar essas avaliações. Ciência e Agrotecnologia, 29(5), 1015-1020. http://dx.doi.org/10.1590/S141370542005000500015

Nascimento, L. C., Lima, L. C. O., Picolli, R. H., Fiorini, J. E., Duarte, S. M. S., Silva, J. M. S. F., Oliveira, N. M. S., \& Veiga, S. M. O. (2008). Ozônio e ultra-som: processos alternativos para o tratamento do café despolpado. Ciência e Tecnologia de Alimentos, 28(2), 282-94. http://dx.doi.org/10.1590/S0101-20612008000200004
Oliveira, M. D. M., Veiga, A. A., Vegro, C. L. R., Mattosinho, P. S. V., \& Moricochi, L. (2005). Investimentos e rentabilidade na produção de café especial: um estudo de caso. Informações Económicas, 35(9), 17 25.

Prete, C. E. C. (1992). Condutividade elétrica do exsudato de grãos de café (Coffea arabica L.) e sua relação com a qualidade da bebida (Tese de doutorado). Escola Superior de Agricultura Luiz de Queiroz, Piracicaba.

Resende, O., Afonso Junior, P. C., Corrêa, P. C., \& Siqueira, V. C. (2011). Qualidade de café conilon submetido a secagem em terreiro híbrido e concreto. Ciência e Agrotecnologia, 35(2), 327-335. http://dx.doi. org/10.1590/S1413-70542011000200014

Silva A. F., Minim, V. P. R., \& Ribeiro, M. M. (2005). Analise sensorial de diferentes marcas comerciais de café (Coffea arabica L.) orgânico. Ciência e Agrotecnologia, 29(6), 1224-230. http://dx.doi.org/10.1590/ S1413-70542005000600017

Silva, R. F., Pereira, R. G. F. A., Borem, F. M., \& Muniz, J. A. (2004). Qualidade do café cereja descascado na região sul de Minas Gerais. Ciência e Agrotecnologia, 28(6), 1367-375. http://dx.doi.org/10.1590/ S1413-70542004000600020

Specialty Coffee Association of America - SCAA. (2008). Protocolo para Análise Sensorial do Café / Metodologia da Associação Americana de Cafés Especiais. Retrieved from www.bsca.com.br.

Theodoro, V. C. A., Carvalho, J. G., Correa, J. B., \& Guimaraes, R. J. (2003). Avaliação do estado nutricional de agroecossistemas de café orgânico no estado de Minas Gerais. Ciência e Agrotecnologia, 27(6), 12221230. http://dx.doi.org/10.1590/S1413-70542003000600003 